\title{
Association of parents' physical activity and weight status with obesity and metabolic risk of their offspring
}

\author{
Associação do status de atividade física e peso dos pais \\ com os indicadores de obesidade e risco metabólico dos filhos
}

\begin{abstract}
André Oliveira Werneck (https://orcid.org/0000-0002-9166-4376) ${ }^{1}$
Danilo Rodrigues Pereira da Silva (https://orcid.org/0000-0003-3995-4795) 1,2

Ellen Caroline Mendes da Silva (https://orcid.org/0000-0001-9856-0054) ${ }^{2}$

Paul Collings (https://orcid.org/0000-0003-2022-5453) ${ }^{3}$

David Ohara (http://orcid.org/0000-0003-0477-8234) ${ }^{4}$

Rômulo Araújo Fernandes (https://orcid.org/0000-0003-1576-8090) ${ }^{5}$

Décio Sabbatini Barbosa (https://orcid.org/0000-0002-8677-4730) ${ }^{6}$

Enio Ricardo Vaz Ronque (https://orcid.org/0000-0003-3430-3993) ${ }^{1}$

Luís Bettencourt Sardinha (https://orcid.org/0000-0002-6230-6027) ${ }^{7}$

Edilson Serpeloni Cyrino (https://orcid.org/0000-0001-9016-8779) ${ }^{1}$
\end{abstract}

\footnotetext{
${ }^{1}$ Grupo de Estudo e Pesquisa em Metabolismo, Nutrição e Exercício - GEPEMENE, Universidade Estadual de Londrina. Rodovia Celso Garcia Cid, km 380. 86057970 Londrina PR Brasil. andreowerneck@gmail.com ${ }^{2}$ Departamento de Educação Física, Universidade Federal de Sergipe. São Cristóvão SE Brasil.

${ }^{3}$ Bradford Institute for Health Research, Bradford NHS Foundation Trust. Bradford United Kingdom. ${ }^{4}$ Departamento de Ciências da Saúde, Universidade Estadual de Santa Cruz.

Ilhéus BA Brasil

${ }^{5}$ Grupo de Investigações

Científicas Relacionadas à

Atividade Física (GICRAF),

Laboratório de Investigação em Exercício (LIVE),

Departamento de Educação Física, Universidade Estadual Paulista "Júlio de Mesquita Filho”. Presidente Prudente SP Brasil.

${ }^{6}$ Departamento de Patologia, Análises Clínicas e Toxicológicas, Centro de Ciências da Saúde, Hospital Universitário, Universidade Estadual de Londrina. Londrina PR Brasil

${ }^{7}$ Exercise and Health Laboratory, CIPER, Faculdade Motricidade Humana, Universidade Lisboa. Cruz-Quebrada Portugal.
}

Resumo Nosso objetivo foi analisar a associação combinada entre características dos pais e indicadores de adiposidade dos filhos com o risco metabólico em adolescentes. Foi realizado estudo transversal com 972 adolescentes e seus pais. Observamos que adolescentes com sobrepeso que possuem mãe com peso normal apresentaram menor risco metabólico em comparação com seus pares com mães que apresentam sobrepeso. Concluímos que o status de peso da mãe modera a relação entre indicadores de obesidade e risco metabólico dos adolescentes.

Palavras-chave Obesidade infantil, Pais, Síndrome metabólica 


\section{Introduction}

Alongside the technological revolution, and the emergence of the epidemiological transition, chronic diseases have become the most common cause of death worldwide ${ }^{1}$. The prevalence of chronic diseases, such as hypertension and type II diabetes, is high in adults and has been increasing in young populations, especially in overweight and obese children and adolescents ${ }^{2}$. Combating early-onset obesity in childhood may be a fruitful way of reducing child morbidity and chronic disease risk in adulthood, but it is currently one of the main challenges of public health ${ }^{3}$.

The determinants of obesity are multifactorial and may include diverse influences from infections, or ambient temperature affecting thermoregulation, to intrauterine and intergenerational factors ${ }^{4}$. There are, however, some recognized pathways for heightened obesity and metabolic risk, including high-energy diets, low physical activity levels, socioeconomic and genetic factors ${ }^{5}$. Parental influences on youth health outcomes are being studied, such as associations between maternal physical activity level during gestation and offspring health in the short-term ${ }^{6}$ and associations between parental obesity and long-term cardiovascular risk in children when middle-aged ${ }^{7}$. Thus, it appears plausible that parental characteristics can influence childhood obesity propensity via a combination of behavioral $^{8}$ and biological pathways ${ }^{7}$.

In the British Birth Cohort Study, Cooper et al. ${ }^{7}$ found a positive association between parental obesity with cardiovascular risk factors in their adult offspring. Moreover, Khanolkar et al. ${ }^{8}$ found relationships between parental behavioral and biological risk factors with children's metabolic risk using a Swedish sample. Nonetheless, to the best of our knowledge, no study has investigated the relation between parental biology and behavior with offspring obesity and metabolic risk in a low to middle income country.

Countries with a different economic and social structure, such as Brazil, for example, which is marked by deep social inequalities, which may be factors that limiting the access to physical exercise and healthier living habits, especially for people with low income. Therefore, given that broader social determinants could explain health behaviors and metabolic risk in low to middle income countries ${ }^{9}$, it is suppose that the relationship between parental biology/behavior and obesity and metabolic risk of their offspring could be different from high-developed countries. Thus, our aim was to analyze the joint association of parental health characteristics (weight status and physical activity) and offspring obesity indicators with metabolic risk in adolescents from Southern Brazil.

\section{Methods}

\section{Sample}

This was a cross-sectional study conducted in adolescents aged between 10 and 16 yearsold who were enrolled in a project from public schools at Londrina/PR, Brazil in 2011, named "Prevalence of metabolic syndrome and cardiovascular risk factors in adolescents from Londrina". Recruitment to the study was performed in two stages. First, all public schools in the city were separated into regions (north, south, east, west and center) and two schools were randomly selected from each region to participate in the study. Second, classes within schools were randomly selected, and all students within those classes received an invitation to the study. Students who were concurrently using prescription medicine, who were undergoing treatment for an illness, or who failed to return a signed parent consent form were all excluded. In total, 1,395 adolescents were successfully recruited, but due to incomplete data especially from parental variables, total sample ranged between 719 (paternal data) and 972 adolescents. Additional information about sampling process is previously published $^{10}$. The local ethics committee approved all of the study's procedures, which adhered to the principles of the Declaration of Helsinki.

\section{Metabolic risk}

Blood pressure was measured on the right arm after a rest period of ten minutes using automatic apparatus (OMRON - HEM-742) that has been validated in adolescents ${ }^{11}$. Two measurements interspersed with a rest interval of two minutes were made and the arithmetic mean of values was calculated. If the difference between measurements was greater than $10 \mathrm{mmHg}$ for systolic (SBP) and diastolic blood pressure (DBP) then a third measurement was performed. In this case, the two closest values were used to inform the mean.

Laboratory tests to estimate fasting glucose, triglycerides and high-density lipoprotein cholesterol (HDL-C) were conducted by trained as- 
sessors of the biochemistry laboratory from the university hospital of Londrina State University. In the school, blood samples were collected after a 12 hour fast from the antecubital vein, either in serum tubes (no anticoagulant) or for the determination of glucose a tube containing an anticoagulant fluoride preservative. Tubes were centrifuged at 3,000 rpm for 5 minutes at $4^{\circ} \mathrm{C}$ to separate plasma and serum. Analyzes were performed immediately following separation of materials using a biochemical auto analyzer (Dimension RxL Max - Siemens Dade-Behring).

A continuous metabolic risk score was derived by summing $\mathrm{z}$-scores for triglycerides, fasting glucose, HDL-C (with opposite sign) and the arithmetic mean of systolic and diastolic blood pressures ((calculation: triglycerides $z+$ fasting glucose $\left.\mathrm{z}+\left[-1^{\star} \mathrm{HDL}-\mathrm{C} \mathrm{z}\right]+[\{\mathrm{SBP} \mathrm{z}+\mathrm{DBP} \mathrm{z}\} / 2]\right)$ $/ 4)^{12}$. We did not include waist circumference in the score, because of the relation with body mass index, as we previously showed ${ }^{13}$.

\section{Adolescents' obesity indicators}

Central adiposity was ascertained by measurement of waist circumference between the lowest rib and the upper edge of the iliac crest to the nearest $0.1 \mathrm{~cm}$ and classified according Katzmarzyk et al. ${ }^{14}$. Three measurements were collected for each participant and the median was used. Subscapular and triceps skinfold thicknesses were measured, according to the Boileau ${ }^{15}$ recommendations, by a trained evaluator using a calibrated (to a precision of $0.5 \mathrm{~mm}$ ) Lange caliper. The technical error of measurements (TEM) was $4.8 \%$ and $3.5 \%$ for subscapular and triceps skinfolds, respectively, and from measurements the percentage of body fat was estimated and classified according Williams et al. ${ }^{16}$. Body mass index (BMI, $\mathrm{kg} / \mathrm{m}^{2}$ ) was calculated from measured weight and height, both of which exhibited good $\mathrm{TEMs}^{10}$ and classified according Onis et al. ${ }^{17}$.

\section{Parents'variables}

Maternal and paternal BMI were calculated using self-reported values for weight and height in response to questionnaires that were answered by each parent. Previous studies have reported good validity of self-reported weight and height in Brazilian adults ${ }^{18}$. Parents were categorized as overweight if BMI was $25 \mathrm{~kg} / \mathrm{m}^{2}$ or more ${ }^{19}$. Physical activity levels were self-reported using the Baecke questionnaire, which captures information regarding about exercise practice and time of practice (Baecke et al., 1988) as well as physical activity in transportation, leisure and occupational domains, through Likert scales. Parents that reported themselves to be physically active for more than $120 \mathrm{~min} /$ week (moderate to vigorous physical activity at least for four months) were classified as active. The questionnaires were delivered to the parents through the adolescents.

\section{Covariates}

Somatic maturation was used as biological maturity indicator. Specifically, age at peak height velocity (PHV) was estimated by combining anthropometric measures with a published, commonly implemented, prediction equation ${ }^{20}$. We have previously described the specific details of this method ${ }^{21}$. Socioeconomic status (SES) was assessed by means of the Brazilian Criterion for Economic Classification instrument ${ }^{22}$, which provides a score based on the education of the household leader and ownership of certain possessions. We classified participants from classes C to $\mathrm{E}$ as with low socioeconomic status.

\section{Statistical analysis}

Descriptive statistics are presented with median, interquartile range and frequencies. Kolmogorov-Smirnov test was used to verify data distribution. Once some variables did not present a normal distribution, we used Mann-Whitney's test and chi-square to compare boys against girls. The Spearman's rank-order correlation was used to verify the relationship of covariates, adolescents' adiposity indicators and parents' variables with the adolescents' metabolic risk score. The biserial correlation coefficient was used to obtain the correlation between the nominal variables and the metabolic risk score.

Subsequently, we calculated the estimated marginal means of metabolic risk score and tested if associations between adolescent adiposity (BMI, waist circumference and body fat; each modelled separately) and metabolic risk were modified by parental weight or physical activity status using Generalized Estimating Equations (GEE). GEE has been proposed for non-normally distributed data with advantages to fit models and to generate population-level parameters. Further details can be found elsewhere ${ }^{23}$. Evidence for effect moderation was considered statistically significant when the $p$-interaction term was $<0.05^{24}$, adjusted for sex, chronological age, socioeconomic status, and age of PHV. All analy- 
ses were conducted using the software Stata 15.1 (StataCorp. College Station, TX, USA).

\section{Results}

Descriptive statistics for the sample are presented in Table 1. Boys were older and had a later estimated age at PHV than girls. With regards to metabolic risk factor characteristics, boys had a larger waist circumference, higher SBP, higher fasting glucose levels, and lower HDL-C than girls. In opposite, girls had higher total percentage body fat, marginally higher DBP, and higher triglyceride concentrations. There were no sex differences in paternal BMI or the proportion of parents classified as "active".

Table 2 shows correlations of covariates, adolescents and parents' level variables with metabolic risk score. We observed significant ( $\mathrm{p}<$ $0.05)$ and directly $(+)$ correlations of chronological age, all three adolescents' adiposity indicators and maternal BMI and metabolic risk score. Age of the peak height velocity was inversely correlated to the outcome.

Estimated marginal means of metabolic risk score for joint groups of adolescent obesity indicators and parental characteristics (physical activity and weight status) as well as the interaction
Table 2. The Spearman's rank-order correlation between adolescents and parents' levels variables with metabolic risk score (Londrina/PR, 2011).

\begin{tabular}{lcc}
\hline & \multicolumn{2}{c}{$\begin{array}{c}\text { Metabolic risk } \\
\text { score }\end{array}$} \\
\hline & Rho & p-value \\
\hline Covariates & & \\
$\quad$ Sex (male/female) & 0.003 & 0.936 \\
$\quad$ Chronological age, years & 0.095 & 0.003 \\
$\quad$ Age of peak height velocity, & -0.066 & 0.039 \\
$\quad$ years & & \\
$\quad \begin{array}{l}\text { Socio-economic status } \\
\text { (classes) }\end{array}$ & 0.057 & 0.100 \\
Adolescents' level & & \\
$\quad$ BMI, kg/m & & \\
$\quad$ Waist circumference, cm & 0.178 & $<0.001$ \\
$\quad$ Body fat, \% & 0.137 & $<0.001$ \\
Parents' level & & \\
$\quad \begin{array}{l}\text { Maternal BMI, kg/m }{ }^{2} \\
\text { Paternal BMI, kg/m }{ }^{2}\end{array}$ & 0.109 & 0.003 \\
$\quad \begin{array}{l}\text { Maternal physical activity } \\
\text { (active/inactive) }\end{array}$ & 0.060 & 0.137 \\
$\quad \begin{array}{l}\text { Paternal physical activity } \\
\text { (active/inactive) }\end{array}$ & 0.003 & 0.936 \\
\hline
\end{tabular}

Note: BMI, body mass index; Parents was classified as active when reported more than $120 \mathrm{~min} /$ week of moderate to vigorous physical activity (at least for four months). The biserial correlation coefficient was used to obtain the correlation between the nominal variables and the metabolic risk score.

Source: Authors.

Table 1. General characteristics of the sample according to sex (Londrina/PR, 2011).

\begin{tabular}{lrrr} 
& $\begin{array}{c}\text { Boys }(\mathbf{n}=\mathbf{4 0 8}) \\
\text { Median }(\mathbf{I Q R})\end{array}$ & $\begin{array}{r}\text { Girls }(\mathbf{n}=\mathbf{5 6 4}) \\
\text { Median (IQR) }\end{array}$ & p \\
\hline Chronological age, years & $13.0(2.2)$ & $12.6(2.2)$ & 0.011 \\
Age of peak height velocity, years & $14.3(0.9)$ & $12.3(0.8)$ & $<0.001$ \\
BMI, kg/m ${ }^{2}$ & $19.0(4.5)$ & $19.2(4.8)$ & 0.280 \\
Waist circumference, cm & $66.5(10.3)$ & $64.3(9.1)$ & $<0.001$ \\
Body fat, \% & $16.9(10.2)$ & $25.3(6.2)$ & $<0.001$ \\
Systolic blood pressure, mmHg & $111(16)$ & $110(13)$ & 0.011 \\
Diastolic blood pressure, mmHg & $62(12)$ & $64(10)$ & $<0.001$ \\
Fasting glucose, mg/dl & $90.0(8.0)$ & $89.0(8.0)$ & $<0.001$ \\
HDL-C, mg/dl & $50.0(16.0)$ & $50.0(15.0)$ & 0.192 \\
Triglycerides, mg/dl & $52.5(33.0)$ & $60.0(37.0)$ & $<0.001$ \\
Maternal BMI, kg/m ${ }^{2}$ & $25.5(6.6)$ & $25.7(6.3)$ & 0.586 \\
Paternal BMI, kg/m ${ }^{2}$ & $26.0(5.2)$ & $25.9(4.9)$ & 0.506 \\
Maternal physical activity, \% active & 22.8 & 22.0 & 0.718 \\
Paternal physical activity, \% active & 22.3 & 23.2 & 0.560 \\
Low socio-economic status, \% & 65.5 & 68.3 & 0.332
\end{tabular}

Note: IQR, interquartile range; BMI, body mass index; parents was classified as active when reported more than $120 \mathrm{~min} /$ week of moderate to vigorous physical activity (at least for four months). 
terms are presented in Table 3 . We observed significant interactions $(\mathrm{p}<0.05)$ only of maternal BMI with adolescent BMI, waist circumference and body fat in the prediction of metabolic risk score. Values of metabolic risk score were significantly higher among adolescents with high adiposity (in all three indicators) who had an overweight mother compared to those who had normal weight mothers. However, adolescents with elevated adiposity (all three indicators) who had normal weight mother showed similar metabolic risk score compared to those with normal weight.

\section{Discussion}

Our aim was to analyze the joint association of parental characteristics (weight status and physical activity) and offspring obesity indicators with

Table 3. Estimated marginal means (EMM) of metabolic risk score for joint groups of adolescent obesity indicators and parental characteristics (physical activity and weight status) as well as the interaction terms (Londrina/PR, 2011).

\begin{tabular}{|c|c|c|c|c|}
\hline & \multirow{2}{*}{ EMM } & \multirow{2}{*}{ CI 95\% } & \multicolumn{2}{|c|}{ Interactions } \\
\hline & & & Wald & $\mathbf{p}$ \\
\hline \multicolumn{5}{|l|}{ Body mass index } \\
\hline Normal + active mother & -0.050 & -0.141 to 0.042 & \multicolumn{2}{|c|}{ BMI vs maternal PA } \\
\hline Normal + inactive mother & -0.107 & -0.153 to -0.062 & \multirow[t]{3}{*}{1.465} & \multirow[t]{3}{*}{0.226} \\
\hline Overweight + active mother & 0.204 & 0.045 to 0.363 & & \\
\hline Overweight + inactive mother & 0.275 & 0.178 to 0.371 & & \\
\hline Normal + active father & -0.457 & -0.154 to 0.063 & \multicolumn{2}{|c|}{ BMI vs paternal PA } \\
\hline Normal + inactive father & -0.088 & -0.138 to -0.039 & \multirow[t]{3}{*}{0.669} & \multirow[t]{3}{*}{0.414} \\
\hline Overweight + active father & 0.216 & 0.028 to 0.0403 & & \\
\hline Overweight + inactive father & 0.273 & 0.172 to 0.374 & & \\
\hline Normal + normal weight mother & -0.102 & -0.162 to -0.042 & \multicolumn{2}{|c|}{ BMI vs maternal BMI } \\
\hline Normal + overweight mother & -0.086 & -0.144 to -0.027 & \multirow[t]{3}{*}{7.291} & \multirow[t]{3}{*}{0.007} \\
\hline Overweight + normal weight mother & 0.073 & -0.064 to 0.210 & & \\
\hline Overweight + overweight mother & 0.347 & 0.244 to 0.450 & & \\
\hline Normal + normal weight father & -0.030 & -0.099 to 0.039 & \multicolumn{2}{|c|}{ BMI vs paternal BMI } \\
\hline Normal weight + overweight father & -0.095 & -0.158 to -0.033 & \multirow[t]{3}{*}{0.279} & \multirow[t]{3}{*}{0.597} \\
\hline Overweight + normal weight father & 0.269 & 0.099 to 0.439 & & \\
\hline Overweight + overweight father & 0.263 & 0.152 to 0.374 & & \\
\hline \multicolumn{5}{|l|}{ Waist circumference } \\
\hline Normal + active mother & -0.043 & -0.132 to 0.046 & \multicolumn{2}{|c|}{ WC vs maternal PA } \\
\hline Normal + inactive mother & -0.098 & -0.143 to -0.053 & \multirow[t]{3}{*}{0.809} & \multirow[t]{3}{*}{0.369} \\
\hline High + active mother & 0.250 & 0.073 to 0.426 & & \\
\hline High + inactive mother & 0.300 & 0.193 to 0.403 & & \\
\hline Normal + active father & -0.054 & -0.156 to 0.048 & \multicolumn{2}{|c|}{ WC vs paternal PA } \\
\hline Normal + inactive father & -0.073 & -0.121 to -0.025 & \multirow[t]{3}{*}{0.183} & \multirow[t]{3}{*}{0.669} \\
\hline High + active father & 0.347 & 0.132 to 0.562 & & \\
\hline High + inactive father & 0.271 & 0.162 to 0.379 & & \\
\hline Normal + normal weight mother & -0.098 & -0.157 to -0.039 & \multicolumn{2}{|c|}{ WC vs maternal BMI } \\
\hline Normal + overweight mother & -0.068 & -0.125 to -0.011 & \multirow[t]{3}{*}{7.340} & \multirow[t]{3}{*}{0.007} \\
\hline High + normal weight mother & 0.073 & -0.071 to 0.216 & & \\
\hline High + overweight mother & 0.375 & 0.260 to 0.491 & & \\
\hline Normal + normal weight father & -0.029 & -0.096 to 0.038 & \multicolumn{2}{|c|}{ WC vs paternal BMI } \\
\hline Normal + overweight father & -0.073 & -0.134 to -0.012 & \multirow[t]{3}{*}{0.026} & \multirow[t]{3}{*}{0.871} \\
\hline High + normal weight mother & 0.315 & 0.134 to 0.497 & & \\
\hline High + overweight father & 0.252 & 0.130 to 0.374 & & \\
\hline
\end{tabular}


Table 3. Estimated marginal means (EMM) of metabolic risk score for joint groups of adolescent obesity indicators and parental characteristics (physical activity and weight status) as well as the interaction terms (Londrina/PR, 2011).

\begin{tabular}{lcccc}
\hline & EMM & CI 95\% & Interactions \\
\cline { 4 - 4 } \% fat & & & Wald \\
Normal + active mother & -0.041 & -0.131 to 0.048 & \% fat vs maternal PA \\
Normal + inactive mother & -0.086 & -0.132 to -0.041 & 0.209 & 0.647 \\
High + active mother & 0.228 & 0.061 to 0.396 & \\
High + inactive mother & 0.234 & 0.132 to 0.336 & \\
\hline Normal + active father & -0.052 & -0.157 to 0.052 & \% fat vs paternal PA \\
Normal + inactive father & -0.063 & -0.111 to -0.015 & 0.083 & 0.773 \\
High + active father & 0.288 & 0.087 to 0.489 & \\
High + inactive father & 0.240 & 0.132 to 0.348 & \\
\hline Normal + normal weight mother & -0.093 & -0.153 to -0.032 & \% fat vs maternal BMI \\
Normal + overweight mother & -0.064 & -0.120 to -0.007 & 8.611 \\
High + normal weight mother & 0.033 & -0.096 to 0.163 & \\
High + overweight mother & 0.346 & 0.233 to 0.460 & \\
\hline Normal + normal weight father & -0.028 & -0.098 to 0.042 & \% fat vs paternal BMI \\
Normal + overweight father & -0.064 & -0.124 to -0.003 & 0.007 \\
High + normal weight father & 0.275 & 0.113 to 0.437 & 0.935 \\
High + overweight father & 0.230 & 0.101 to 0.359 & \\
\hline
\end{tabular}

Note: Adjusted by sex, chronological age, socioeconomic status and age of peak height velocity. CI: confidence interval; PA: physical activity. BMI: body mass index; PA: physical activity; WC: waist circumference. Metabolic risk score (adolescent) as outcome. EMMs represent predicted means of metabolic risk score considering all variables included in the models.

Source: Authors.

metabolic risk in adolescent offspring. We identified that the relationship between adolescent obesity indicators and metabolic risk is stronger compared to the parental indicator, however maternal BMI moderates this association between adolescent adiposity and metabolic risk. In other words, among overweight/high adiposity adolescents, those who have an overweight mother tend to have worst metabolic profile compared with their counterparts. For other way, adolescents with elevated adiposity indicator who have normal weight mothers showed similar metabolic risk score than normal weight adolescents.

The negative impacts of obesity during childhood and adolescence are largely studied. Childhood obesity seems to be associated with several outcomes, since psychological, as a lower social acceptation and higher risk of depression ${ }^{25}$, up to cardiovascular risk factors ${ }^{5,25}$. Thus, a better comprehension of correlates of childhood obesity could culminate in the elaboration of more robust strategies of interventions for this outcome.

Among several determinants of obesity in childhood, genetic and environmental factors have been extensively mentioned. In fact, studies have shown that parents' obesity seems to influence obesity indicators in adolescents through different paths ${ }^{26}$. The environmental path can be due to the transference of lifestyle behaviors of parents to their children or even by the importance given for the parents of a healthy lifestyle ${ }^{27}$. Parents can influence behaviors of their children, as feed behavior, physical activity and sedentary behaviors, which contributes with obesity indicators of adolescents ${ }^{27,28}$. Our findings did not show correlation between parental physical activity and adolescents' metabolic risk score, suggesting other potential pathways.

We found that overweight adolescents had higher metabolic risk score, however, those who had a normal weight mother, even being overweight, had lower metabolic risk in comparison of their counterparts (overweight) with overweight mothers. There may be several ways to understand how mothers' weight status changed the relation between obesity indicators and metabolic risk in adolescents. One possible approach would be an indirect way (as well as for obesi- 
ty), through a behavioral influence, in this case, adolescents tend to adopt parent's behaviors and consequently, develop biological risk factors as obesity and higher metabolic risk ${ }^{28}$. Other path of interference of factors related with parents, is direct, through genetic determination ${ }^{29}$. In this case, several cardiovascular risk factors are influenced by genetic load of parents ${ }^{29-31}$. Moreover, an interesting finding was that mothers, but not fathers, moderated the relationship between obesity indicators and metabolic risk in adolescents. This fact can occur due to the local culture ${ }^{32}$. In our case, probably the most part of fathers works outside home and, consequently, mothers had more contact with their children ${ }^{33}$. However, it is important to highlight that due to the cross-sectional design adopted in our study, we cannot determine causality between parental and adolescent characteristics.

To the best of our knowledge, this is the first study investigating the relationship between parent's health characteristics and adolescent's metabolic outcomes in the context of low to middle income countries. Socioeconomic status is one of the strongest predictors of obesity. The lack of knowledge about healthy lifestyles, such as the amount and types of food to be consumed or the importance of active behaviors, can be associated to this. Families of lower socioeconomic status tend to present poorer eating and active habits ${ }^{34}$. Also, products such as fruits and vegetables can be expensive in the budget of the poorest fami$\operatorname{lies}^{35}$, and the availability of fruits and vegetables is also lower in these countries. In this way, increasing the ease of acquiring fruits and vegetables can be a way to increase their consumption, and access to the knowledge of a healthy diet and the practice of physical activity through public policies.

Other practical implications can be inferred from the present findings. Firstly, given the association between maternal weight status and ado- lescent metabolic risk, family approach could be an effective target of interventions. Engagement of parents on childhood obesity interventions for prevention and/or treatment seems to have greater effect on the adolescents' body fat ${ }^{36,37}$. Moreover, family interventions should be focused in the parent that pass the greater time with their offspring, given our results concerning the greatest association between mother's characteristics and offspring than father's characteristics and offspring. Thus, the best way to deliver these interventions should be investigated.

Study limitations include that parental stature, body mass, and physical activity were all self-reported. Reassuringly, good agreement between self-reported and directly measured stature and body mass has previously been reported in Brazilian adults ${ }^{18}$. Objective physical activity measurement is growing in Brazil, but subjective indicators are still more common and we accept that they can introduce bias ${ }^{38}$. In addition, given the instability of weight status during the lifespan, no information about "trajectories" of parents' weight status was obtained. Nonetheless, strengths of this investigation include availability of data in more than 900 Brazilian adolescents, which permitted metabolic risk calculation, and the analyses were adjusted for important confounding factors including chronological age, socioeconomic status and biological maturation.

\section{Conclusion}

Adolescents with elevated waist circumference, weight status and sum of skinfolds have higher metabolic risk. However, among them, those who have a normal weight mother show lower metabolic risk in comparison with their counterparts with overweight mothers. Future studies can analyze these relationships longitudinally (causal relationships), as well as unlock the possible mechanisms of interaction between the factors. 


\section{Collaborations}

AO Werneck: conceptualization, formal analysis, validation, writing - original draft, visualization. DRP Silva: conceptualization, validation, writing original draft, investigation, visualization. ECM Silva: validation, writing - original draft, visualization. P Collins and D Ohara: validation, visualization, writing - review and editing. RA Fernandes and DS Barbosa: validation, visualization, writing - review and editing, project administration. ERV Ronque and ES Cyrino: validation, visualization, writing - review and editing, project administration, supervision. LB Sardinha: validation, visualization, writing - review and editing, supervision.

\section{Acknowledgements}

The authors thank Alessandra Okino, Jair Oliveira and Danielle Venturini for research support. Crisieli Tomeleri, Mariana Carnelossi and Sandra Kawaguti for acquisition of data. Coordenação de Aperfeiçoamento de Pessoal de Nível Superior (CAPES/BRAZIL) for scholarships (DRP Silva) and Conselho Nacional de Desenvolvimento Científico e Tecnológico (CNPq/BRAZIL) for funding the project (483867/2009-8) and for scholarship of scientific initiation (AO Werneck) and productive research (ERV Ronque, ES Cyrino and RA Fernandes).

\section{Funding}

Conselho Nacional de Desenvolvimento Científico e Tecnológico - CNPq/BRAZIL (483867/2009-8).

\section{References}

1. Lee IM, Shiroma EJ, Lobelo F, Puska P, Blair SN, Katzmarzyk PT, Group LPASW. Effect of physical inactivity on major non-communicable diseases worldwide: an analysis of burden of disease and life expectancy. Lancet 2012; 380(9838):219-229.

2. l'Allemand-Jander D. Clinical diagnosis of metabolic and cardiovascular risks in overweight children: early development of chronic diseases in the obese child. Int J Obes (Lond) 2010; 34(Suppl. 2):S32-S36.

3. Lobstein T, Jackson-Leach R, Moodie ML, Hall KD, Gortmaker SL, Swinburn BA, James WP, Wang Y, McPherson K. Child and adolescent obesity: part of a bigger picture. Lancet 2015; 385(9986):2510-2520.

4. McAllister EJ, Dhurandhar NV, Keith SW, Aronne LJ, Barger J, Baskin M, Benca RM, Biggio J, Boggiano MM, Eisenmann JC, Elobeid M, Fontaine KR, Gluckman P, Hanlon EC, Katzmarzyk P, Pietrobelli A, Redden DT, Ruden DM, Wang C, Waterland RA, Wright SM, Allison DB. Ten putative contributors to the obesity epidemic. Crit Rev Food Sci Nutr 2009; 49(10):868-913.

5. Ebbeling CB, Pawlak DB, Ludwig DS. Childhood obesity: public-health crisis, common sense cure. Lancet 2002; 360(9331):473-482.

6. Silva SG, Ricardo LI, Evenson KR, Hallal PC. Leisure-time physical activity in pregnancy and maternalchild health: a systematic review and meta-analysis of randomized controlled trials and cohort studies. Sports Med 2017; 47(2):295-317

7. Cooper R, Pinto Pereira SM, Power C, Hyppönen E. Parental obesity and risk factors for cardiovascular disease among their offspring in mid-life: findings from the 1958 British Birth Cohort Study. Int J Obes (Lond) 2013; 37(12):1590-1596.

8. Khanolkar AR, Byberg L, Koupil I. Parental influences on cardiovascular risk factors in Swedish children aged 5-14 years. Eur J Public Health 2012; 22(6):840847.

9. Braillon A. Social determinants of health: social justice and vested interests. Lancet 2019; 393(10183):18051806.

10. Silva D, Werneck AO, Collings P, Tomeleri CM, Fernandes RA, Ronque E, Venturini D, Barbosa DS, Coelho ESMJ, Sardinha LB, Cyrino ES. Cardiorespiratory fitness is related to metabolic risk independent of physical activity in boys but not girls from Southern Brazil. Am J Hum Biol 2016.

11. Christofaro DGD, Fernandes RA, Gerage AM, Alves MJ, Polito MD, Oliveira AR. Validação do monitor de medida de pressão arterial Omron HEM 742 em adolescentes. Arq Bras Cardiol 2009; 92(1):10-15.

12. Eisenmann JC. On the use of a continuous metabolic syndrome score in pediatric research. Cardiovasc Diabetol 2008; 7:17.

13. Silva DR, Werneck AO, Collings PJ, Ohara D, Fernandes RA, Barbosa DS, Ronque ERV, Sardinha LB, Cyrino ES. Cardiorespiratory fitness effect may be under -estimated in 'fat but fit' hypothesis studies. Ann Hum Biol. 2017;44(3):237-42.

14. Katzmarzyk PT, Srinivasan SR, Chen W, Malina RM, Bouchard C, Berenson GS. Body mass index, waist circumference, and clustering of cardiovascular disease risk factors in a biracial sample of children and adolescents. Pediatrics 2004; 114(2):e198-205. 
15. Boileau RA, Lohman TG, Slaughter MH. Exercise body composition in children and youth. Scandinavian Journal of Sport Sciences 1985; 7:17-27.

16. Williams DP, Going SB, Lohman TG, Harsha DW, Srinivasan SR, Webber LS, Berenson GS. Body fatness and risk for elevated blood pressure, total cholesterol, and serum lipoprotein ratios in children and adolescents. Am J Public Health 1992; 82(3):358-363.

17. de Onis M, Onyango AW, Borghi E, Siyam A, Nishida C, Siekmann J. Development of a WHO growth reference for school-aged children and adolescents. Bull World Health Organ. 2007; 85(9):660-667.

18. Castro V, Moraes SA, Freitas IC. [Agreement of anthropometric measures in a population-based epidemiological study: Ribeirão Preto, SP, 2006. OBEDIARP project]. Rev Bras Epidemiol. 2010; 13(1):58-68.

19. World Health Organization (WHO). Obesity and overweight 2020, March 3 [Internet]. [cted Ano Mês Dia]. Available from: https://www.who.int/en/news -room/fact-sheets/detail/obesity-and-overweight

20. Mirwald RL, Baxter-Jones AD, Bailey DA, Beunen GP. An assessment of maturity from anthropometric measurements. Med Sci Sports Exerc 2002; 34(4):689-694.

21. Werneck AO, Silva DR, Collings PJ, Fernandes RA, Ronque ER, Barbosa DS, Cyrino ES. Biological maturation, central adiposity, and metabolic risk in adolescents: a mediation analysis. Child Obes 2016; 12(5):377-83.

22. Associação Brasileira de Empresas de Pesquisa (ABEP). Critério Brasil: Critério de Classificação Econômica Brasil 2021 [Internet]. [acessado 2021 Dez 11]. Disponível em: http://www.abep.org/criterio-brasil.

23. Pekár S, Brabec M. Generalized estimating equations: a pragmatic and flexible approach to the marginal GLM modelling of correlated data in the behavioural sciences. Ethology 2018; 124(2):86-93.

24. Baron RM, Kenny DA. The moderator-mediator variable distinction in social psychological research: conceptual, strategic, and statistical considerations. J Pers Soc Psychol 1986; 51(6):1173-1182.

25. Campbell MK. Biological, environmental, and social influences on childhood obesity. Pediatr Res 2016; 79(1-2):205-211.

26. Jääskeläinen $\mathrm{A}$, Pussinen J, Nuutinen $\mathrm{O}, \mathrm{Schwab} \mathrm{U}$, Pirkola J, Kolehmainen M, Järvelin MR, Laitinen J. Intergenerational transmission of overweight among Finnish adolescents and their parents: a 16-year follow -up study. Int J Obes (Lond) 2011; 35(10):1289-1294.

27. Haines J, Kleinman KP, Rifas-Shiman SL, Field AE, Austin SB. Examination of shared risk and protective factors for overweight and disordered eating among adolescents. Arch Pediatr Adolesc Med 2010; 164(4):336-343.

28. Kwon S, Janz KF, Letuchy EM, Burns TL, Levy SM. Parental characteristic patterns associated with maintaining healthy physical activity behavior during childhood and adolescence. Int J Behav Nutr Phys Act. 2016;13(1):58

29. Hong Y, Rice T, Gagnon J, Després JP, Nadeau A, Pérusse L, Bouchard C, Leon AS, Skinner JS, Wilmore $\mathrm{JH}$, Rao DC. Familial clustering of insulin and abdominal visceral fat: the HERITAGE Family Study. J Clin Endocrinol Metab 1998; 83(12):4239-4245.
30. Bouchard C, Lesage R, Lortie G, Simoneau JA, Hamel P, Boulay MR, Pérusse L, Thériault G, Leblanc C. Aerobic performance in brothers, dizygotic and monozygotic twins. Med Sci Sports Exerc 1986; 18(6):639646.

31. Speliotes EK, Willer CJ, Berndt SI, Monda KL, Thorleifsson G, Jackson AU, Lango Allen H, Lindgren CM, Luan J, Mägi R, Randall JC, Vedantam S, Winkler TW, Qi L, Workalemahu T, Heid IM, Steinthorsdottir V, Stringham HM, Weedon MN, Wheeler E, Wood AR, Ferreira T, Weyant RJ, Segrè AV, Estrada K, Liang L, Nemesh J, Park JH, Gustafsson S, Kilpeläinen TO, Yang J, Bouatia-Naji N, Esko T, Feitosa MF, Kutalik Z, Mangino M, Raychaudhuri S, Scherag A, Smith AV, Welch R, Zhao JH, Aben KK, Absher DM, Amin N, Dixon AL, Fisher E, Glazer NL, Goddard ME, Heard-Costa NL, Hoesel V, Hottenga JJ, Johansson A, Johnson T, Ketkar S, Lamina C, Li S, Moffatt MF, Myers RH, Narisu N, Perry JR, Peters MJ, Preuss M, Ripatti S, Rivadeneira F, Sandholt C, Scott LJ, Timpson NJ, Tyrer JP, van Wingerden S, Watanabe RM, White CC, Wiklund F, Barlassina C, Chasman DI, Cooper MN, Jansson JO, Lawrence RW, Pellikka N, Prokopenko I, Shi J, Thiering E, Alavere $\mathrm{H}$, Alibrandi MT, Almgren $\mathrm{P}$, Arnold AM, Aspelund T, Atwood LD, Balkau B, Balmforth AJ, Bennett AJ, Ben-Shlomo Y, Bergman RN, Bergmann S, Biebermann H, Blakemore AI, Boes T, Bonnycastle LL, Bornstein SR, Brown MJ, Buchanan TA, Busonero F, Campbell H, Cappuccio FP, Cavalcanti-Proença C, Chen YD, Chen CM, Chines PS, Clarke R, Coin L, Connell J, Day IN, den Heijer M, Duan J, Ebrahim S, Elliott P, Elosua R, Eiriksdottir G, Erdos MR, Eriksson JG, Facheris MF, Felix SB, Fischer-Posovszky P, Folsom AR, Friedrich N, Freimer NB, Fu M, Gaget S, Gejman PV, Geus EJ, Gieger C, Gjesing AP, Goel A, Goyette P, Grallert H, Grässler J, Greenawalt DM, Groves CJ, Gudnason V, Guiducci C, Hartikainen AL, Hassanali N, Hall AS, Havulinna AS, Hayward C, Heath AC, Hengstenberg C, Hicks AA, Hinney A, Hofman A, Homuth G, Hui J, Igl W, Iribarren C, Isomaa B, Jacobs KB, Jarick I, Jewell E, John U, Jørgensen T, Jousilahti P, Jula A, Kaakinen M, Kajantie E, Kaplan LM, Kathiresan S, Kettunen J, Kinnunen L, Knowles JW, Kolcic I, König IR, Koskinen S, Kovacs P, Kuusisto J, Kraft P, Kvaløy K, Laitinen J, Lantieri O, Lanzani C, Launer LJ, Lecoeur C, Lehtimäki T, Lettre G, Liu J, Lokki ML, Lorentzon M, Luben RN, Ludwig B, Manunta P, Marek D, Marre M, Martin NG, McArdle WL, McCarthy A, McKnight B, Meitinger T, Melander O, Meyre D, Midthjell K, Montgomery GW, Morken MA, Morris AP, Mulic R, Ngwa JS, Nelis M, Neville MJ, Nyholt DR, O’Donnell CJ, O’Rahilly S, Ong KK, Oostra B, Paré G, Parker AN, Perola M, Pichler I, Pietiläinen KH, Platou CG, Polasek O, Pouta A, Rafelt S, Raitakari O, Rayner NW, Ridderstråle M, Rief W, Ruokonen A, Robertson NR, Rzehak P, Salomaa V, Sanders AR, Sandhu MS, Sanna S, Saramies J, Savolainen MJ, Scherag S, Schipf S, Schreiber S, Schunkert H, Silander K, Sinisalo J, Siscovick DS, Smit JH, Soranzo N, Sovio U, Stephens J, Surakka I, Swift AJ, Tammesoo ML, Tardif JC, Teder-Laving M, Teslovich TM, Thompson JR, Thomson B, Tönjes A, Tuomi T, van Meurs JB, van Ommen GJ, Vatin V, Viikari J, Visvikis-Siest S, Vitart V, Vogel CI, Voight BF, Waite LL, Wallaschofski H, 
Walters GB, Widen E, Wiegand S, Wild SH, Willemsen G, Witte DR, Witteman JC, Xu J, Zhang Q, Zgaga L, Ziegler A, Zitting P, Beilby JP, Farooqi IS, Hebebrand J, Huikuri HV, James AL, Kähönen M, Levinson DF, Macciardi F, Nieminen MS, Ohlsson C, Palmer LJ, Ridker PM, Stumvoll M, Beckmann JS, Boeing H, Boerwinkle E, Boomsma DI, Caulfield MJ, Chanock SJ, Collins FS, Cupples LA, Smith GD, Erdmann J, Froguel P, Grönberg H, Gyllensten U, Hall P, Hansen T, Harris TB, Hattersley AT, Hayes RB, Heinrich J, Hu FB, Hveem K, Illig T, Jarvelin MR, Kaprio J, Karpe F, Khaw KT, Kiemeney LA, Krude H, Laakso M, Lawlor DA, Metspalu A, Munroe PB, Ouwehand WH, Pedersen O, Penninx BW, Peters A, Pramstaller PP, Quertermous T, Reinehr T, Rissanen A, Rudan I, Samani NJ, Schwarz PE, Shuldiner AR, Spector TD, Tuomilehto J, Uda M, Uitterlinden A, Valle TT, Wabitsch M, Waeber G, Wareham NJ, Watkins $\mathrm{H}$, Wilson JF, Wright AF, Zillikens MC, Chatterjee N, McCarroll SA, Purcell S, Schadt EE, Visscher PM, Assimes TL, Borecki IB, Deloukas P, Fox CS, Groop LC, Haritunians T, Hunter DJ, Kaplan RC, Mohlke KL, O’Connell JR, Peltonen L, Schlessinger D, Strachan DP, van Duijn CM, Wichmann HE, Frayling TM, Thorsteinsdottir U, Abecasis GR, Barroso I, Boehnke M, Stefansson K, North KE, McCarthy MI, Hirschhorn JN, Ingelsson E, Loos RJ, MAGIC, Consortium P. Association analyses of 249,796 individuals reveal 18 new loci associated with body mass index. Nat Genet 2010; 42(11):937-948.

32. McCarthy K, Ye YL, Yuan S, He QQ. Parental weight status and offspring cardiovascular disease risks: a cross-sectional study of Chinese children. Prev Chronic Dis 2015; 12:E01.
33. Instituto Brasileiro de Geografia e Estatística (IBGE). Pesquisa Nacional por Amostra de Domicílios: síntese de indicadores 2014. Rio de Janeiro: IBGE; 2015.

34. Best M, Papies EK. Lower socioeconomic status is associated with higher intended consumption from oversized portions of unhealthy food. Appetite 2019; 140:255-268.

35. Cassady D, Jetter KM, Culp J. Is price a barrier to eating more fruits and vegetables for low-income families? J Am Diet Assoc 2007; 107(11):1909-1915.

36. Dobbins M, Husson H, DeCorby K, LaRocca RL. School-based physical activity programs for promoting physical activity and fitness in children and adolescents aged 6 to 18. Cochrane Database of Syst Rev; 2013(2):CD007651.

37. Teder M, Mörelius E, Bolme P, Nordwall M, Ekberg J, Timpka T. Family-based behavioural intervention programme for obese children: a feasibility study. BMJ Open 2012; 2(2):e000268.

38. Hallal PC, Dumith SC, Bastos JP, Reichert FF, Siqueira FV, Azevedo MR. Evolution of the epidemiological research on physical activity in Brazil: a systematic review. Rev Saude Publica 2007; 41(3):453-460.

Article submitted 27/09/2019

Approved 29/03/2021

Final version submitted 31/03/2021

Chief editors: Romeu Gomes, Antônio Augusto Moura da Silva 